\title{
HISTORIA Y BIODIVERSIDAD EN EL PERÚ
}

\author{
HISTORY AND BIODIVERSITY IN PERU
}

Ernesto Yepes ${ }^{l}$

No me cabe duda de que la de 1990 será una década que en el futuro encenderá viva polémica entre nuestros historiadores de mañana; esto es, entre los fedatarios del siglo XXI encargados de registrar, auscultar y valorar nuestro paso por la centuria que acababa de concluir.

A esos estudiosos les asombrará contrastar de un lado nuestra algarabía desbordante al recordar 1492, la fecha cabalística en que la Europa renacentista descubrió América, y del otro, observarán, quizá incrédulos, nuestro casi púdico silencio frente a otro hecho no menos portentoso: el descubrimiento del Perú por los mestizos descendientes de los Colón y los Pizarro, quinientos años más tarde. Por supuesto, este reciente descubrimiento tiene casi la misma huella que trazaron nuestros ya lejanos parientes peninsulares.

Las ciudades, sobre todo las costeñas, se han convertido en nuestro San Salvador, nuestra Isla Guahananí. De esa Isla-fortaleza miramos con sigilo el continente. Un continente, que como en los tiempos del genovés, pudiera ser Catay, Sipán o cualquier otro reino. Después de todo, más allá de las fronteras donde empiezan los Andes y sobretodo, de esa sabana inmensa e inhóspita que es la amazonía cabe cualquier sorpresa. Son tierras peligrosas asoladas por salvajes

Nuestras expediciones a tan remotos parajes también han buscado -y conseguido, con diferente éxito- el apoyo financiero real. No de los Reyes Católicos obviamente, sino de sus pares más bien protestantes.

En las cortes de Londres primero y Washington más tarde aprendimos a medias las artes del lobby, de la intriga cortesana, a fin de lograr que su divina gracia nos conceda el privilegio de descubrir para ella nuestro país.

Armamos así sendas expediciones al país del guano, al de la caña de azúcar y el algodón, al del caucho, al de las lanas, y naturalmente, al codiciado reino del oro plata, cobre y otros minerales.

En algunos casos, cuando los peligros o los recursos necesarios eran muy grandes y también, por qué no, las utilidades, llegaron expediciones financiadas, organizadas y dirigidas directamente desde el Támesis o el río Potomac.
Nuestros historiadores han registrado con sigilo, dedicación y minuciosidad los detalles de esta grandiosa odisea. Los desafíos fueron extraordinarios. Hubo que adentrarse en los confines del macizo andino. En algunos casos llegar al país de los nativos, de los indios, arriba de los 3,500 metros, a fin de 'persuadirlos' que bajen a los valles y a la costa para que trabajen como si fueran esclavos. En otros, tuvieron que horadar el llano amazónico y persuadir a los aborígenes de perder sus tierras y vidas a fin de ubicar, arrancar y transportar la flora y la fauna susceptibles de convertirse en finas maderas y otras lindezas.

Por fortuna, no siempre fue necesario adentrarse a territorios lejanos o inhóspitos. Claro que también en esas comarcas más amables y afines a nuestra sensitiva piel y perfilado gusto -valles costeños y no pocos interandinos- crecían desafiantes especies vegetales $y$ animales indeseables, casi satánicos, que había que extirpar antes que contaminaran, limitaran o, en términos más apropiados, corrompieran a las pocas pero selectas formas de vida que en adelante merecieron el honor de vivir sobre estas tierras.

Y así lo que hoy llamamos reino natural, lo que constituye el milenario y riquísimo reino de la vida sobre este territorio, empezó a fragmentarse en dos grandes troncos de seres vivos.

De un lado unos cuantos, los elegidos, los favoritos de la corte anglosajona. Y de otro, los parias, los ignorados, los perseguidos, como el gossipiun peruvianum, el algodón rústico de trayectoria inmemorial y artífice de un arte textil de milenios, acusado de corromper a sus pares traídos de allende los mares, como el algodón pima.

Este era nuestro mundo hasta no hace sino unas décadas: sencillo, ordenado. Y sobre todo claramente delimitado. Cada quien ocupaba y conocía su sitio, y también su destino, tanto hombres, como plantas y animales.

Por supuesto que había guerras civiles. Pero al final eran pleitos entre señores aficionados a la cacería o a la matanza o al botín, que contaban, cómo no, con sus huestes de indios.

\footnotetext{
PhD porla Universidad de Manchester(U.K), Historiador. Docente emérito de la Universidad Nacional Agraria La Molina y Pontificia Universidad Católica del Perú. Correoelectrónico:eyepesdelcastillo@gmail.com
} 
Y así guerreaban los del norte contra los del sur, los del valle contra los de la altura, los de arriba contra los de abajo. Por lo demás, todo el resto permanecía igual. Éramos un reino pacífico.

Pero un buen día comenzó a alterarse este orden que parecía casi inmutable, convencidos quizá por su terca persistencia de varios siglos. Sigilosa, imperceptiblemente primero, a raudales y en masa después, los bárbaros empezaron a infiltrarse en nuestra isla fortaleza, en nuestra Guanahaní criolla. Uno a uno fueron corroyendo los torreones, las murallas.

Como hormigas incansables, desmontaron los fragmentos de cada ladrillo y cada adobe y se fueron apropiando de todo cuanto fue posible: calles, plazas, chacras, terrenos baldíos, faldas de los cerros, arenales.

Hombres, mujeres, viejos, jóvenes y niños, en fin miles, millones sin proponérselo, nos bajaron implacables las cortinas, las anteojeras, como dirían los escribidores actuales.

Descubrimos entonces frente a nuestra casa el verdadero rostro del Perú. El imperceptible, el que estábamos persuadidos que no existía. En suma, el que nos habíamos negado a ver.

\section{¿Por Fin, Tierra Firme?}

No hay que ser muy sagaz para advertir que aún no terminamos de reponernos del "shock', del terremoto social y mental que ha significado para nosotros este neo descubrimiento del Perú. En este estado de ánimo -por fortuna, quizá ya predispuesto para las sorpresas- esta década, la de 1990, la signada por el recuerdo de los 500 años de Europa y el mundo en América, nos promete una nueva conmoción. Intensa como la anterior e incitada también por un descubrimiento. Sólo que esta vez la fuerza impulsora, el epicentro de nuestro terremoto mental se ubica en el corazón mismo de las cortes imperiales, de los países a los que tradicionalmente hemos tomado como referente de nuestro futuro y también, con pudores momentáneos, de nuestra identidad.

Ocurre que de esas cumbres del poder han empezado a llegarnos nuevos códigos, sugerencias, recomendaciones, instrucciones -en fin, el nombre técnico dependerá de la nomenclatura con que nos sintamos menos incómodos- encaminados a cuestionar uno de nuestros dogmas más preciados: el de la santidad de nuestra misión evangélica pro-progreso en estas tierras pródigas en hombres, plantas y animales impuros. Nos llegan mensajes que amenazan minar las bases de nuestras convicciones más firmes de lo que es el Perú, sobre todo el de mañana, conminándonos prácticamente a redescubrir -por fin- nuestro espacio nacional, nuestra inmensa riqueza biológica hasta ahora excomulgada; obligándonos, herejía de herejías, a aceptar lo inaceptable, la sabiduría providencial de los vencidos, de los marginados, de los impuros. En suma, que el Perú que arrinconamos, despreciamos, excluimos, y con ahinco destruimos, es ahora el Perú que hay que salvar antes que sea demasiado tarde. Tarde no tanto para los que habitan estos territorios sino principalmente para los países que hasta ayer nos premiaban por hacer lo contrario.

La interrogante que se levanta entonces para muchos de nosotros, quizá los menos informados, es insoslayable: ¿qué vincula tan estrechamente nuestro tardío redescubrimiento del Perú a los avatares, transformaciones y necesidades del occidente industrial desarrollado? ¿Por qué ese occidente amenaza ahora nuestra legitimidad, incluso nuestra membresía a él, si precisamente por ser sus seguidores más devotos, sus avanzadas más leales, desconocimos nuestra diversidad étnica a nombre de un hombre blanco, único ser racional verdadero? ¿Por qué, si fue como representantes de esa estirpe infalible que impusimos un implacable cartabón a formas de vida animal y vegetal de variedad infinita, condenando al patíbulo a miles de especies vegetales y animales que estorbaban o eran innecesarias a los requerimientos del orden imperial? ¿Qué ha cambiado en Occidente que trastoca en cierto modo la legitimidad de muchas de nuestras convicciones básicas y que nos impele a mirar con ojos positivos a los marginados y a los perseguidos? ¿Qué nos obliga a incluir en los mapas del Perú oficial espacios hasta hoy alejados de la gracia de Dios y del Estado, del capital y de los académicos? ¿Qué nos obliga, en fin, a mantener vigente nuestra filiación a occidente a condición de que esta vez sí asumamos sin pudores nuestra identidad social, cultural y nacional, incluyendo en esta última, naturalmente, a uno de sus componentes más preciosos: el espacio físico y su riqueza biológica? En suma, nuestra membresía al mundo moderno, al ámbito del progreso, nos plantea ahora una exigencia: descubrir, conocer o reconocer un país que durante siglos destruimos e ignoramos a nombre de ese mismo progreso.

Las páginas que siguen intentan ofrecer más que respuestas, algunas reflexiones tentativas y esquemáticas, con relación a esta interrogante.

Quizá por ello también el lenguaje sea menos coloquial, más confuso y más atado a las veleidades del lenguaje académico que como bien sabemos nos protege cuando las ideas no están lo suficientemente claras y queremos sin embargo que logren parecerlo.

\section{El nuevo contexto internacional}

Hasta no hace mucho las relaciones entre el norte y el sur, entre los países ricos y los 


\section{La Vida y la Historia}

Yepes, E. Historia y Biodiversidad en el Perú

subdesarrollados eran relativamente simples. Exportábamos materias primas. Les comprábamos bienes acabados. Por supuesto que entre ambos polos había diferencias de grado y de combinaciones. Pero a grandes líneas ésa era la tendencia básica.

La voz cantante en ese orden internacional a la medida la tenían los países dueños de las industrias de humo y chimeneas, en cuyas calderas se gestaba la arquitectura del aparato productivo industrial del orbe y a cuyo servicio se organizaba el consumo moderno de todos los pueblos del planeta. Para ese orden mundial así estructurado, el Perú como los demás países andinos hubieron de adecuar su espacio físico y social. El ámbito agropecuario constituye un excelente ejemplo de estos hechos. Tierra, aire, agua, de una forma u otra debieron adecuarse a los requerimientos de ese patrón de crecimiento que rendía culto a la homogeneización de los seres vivos de la tierra en tanto hijos legítimos de un orden industrial, urbano, amante devoto de la producción y consumo en grandes magnitudes. La historia, nuestra historia, lo señalamos antes, registró con fidelidad y orgullo los avatares de esas transformaciones espectaculares. Pero se olvidó de registrar en sus grandes libros contables junto a la tierra, el aire y el agua, un cuarto componente, quizá el fundamental, de su disputado patrimonio, su riqueza genética.

$\mathrm{Y}$ es que ocurre que esa riqueza se encuentra precisamente en el complejo andino-amazónico, en esa región nefasta que impide que los estrechos, valles costeños se prolonguen lo suficiente como para convertirse en un paisaje similar al de California o de Wisconsin. Ocurre que nuestro macizo andino, avaro en tierras planas y profundas como el paisaje europeo, no sólo constituye el gran banco minero que encandiló al peninsular, al anglosajón y a los presupuestos y ambiciones del Perú republicano, sino que también constituye uno de los más formidables bancos biológicos del planeta.

Diversidad de ecosistemas, diversidad de especies y diversidad genética constituyen quizá nuestra riqueza más portentosa. Más valorada, desde siempre, por las metrópolis que por la élite económica y política que manejó el Perú republicano. Después de todo, en nuestros libros de lamentaciones tirios y troyanos hemos anotado entre polémicas y desacuerdos la cantidad de plata y oro $-y$ otras riquezas parecidasque se llevó la Europa imperial; las más de 150 especies nativas domesticadas por el poblador andino en siglos de tenaz esfuerzo cultural y que se volcaron después al mundo desarrollado; las 1200 especies silvestres que registraron sus científicos porque podían tener alguna aplicación eventual bien como alimentos, medicinas, insumos, etcétera; después de todo eran y son, para nosotros, en su mayor parte plantas de indios y para indios, de las que había que enorgullecerse protocolarmente en los museos y en las efemérides dedicadas a la raza, al indio o al campesino, dependiendo, claro ésta, del líder de tumo en la Casa de Pizarro.

Pero ocurre que hoy una revolución científico tecnológica conmociona al mundo industrial desarrollado. Una revolución en la que cifra sus más caras esperanzas para corregir y desandar algunos de los graves problemas derivados precisamente de su patrón de desarrollo uniformador y de gran escala. Un buen ejemplo de este desencuentro lo encontramos en la crisis de la agricultura moderna. Una agricultura que reposando en variedades mejoradas, mayores rendimientos $\mathrm{y}$ alto componente de energía de combustibles fósiles, han conducido a un dramático empobrecimiento genético que amenaza las bases mismas del desarrollo agropecuario considerado moderno.

Naturalmente en esta nueva coyuntura no es precisamente nuestra riqueza minera lo que encandila más al occidente desarrollado. Es nuestra riqueza genética. Si no, recordemos un didáctico y tradicional ejemplo: en nuestros 84 ecosistemas o zonas de vida con que contamos- de los 120 que existen en el mundo habitan 35 mil especies de plantas superiores y unas 3780 especies de animales. Sin contar, claro está, los 30 millones de variedades de insectos que tenemos en la amazonia.

En la revolución científico-tecnológica en marcha, el conocimiento convertido en capitalconocimiento, está impulsando aceleradamente el desarrollo de nucvas tecnologías y nuevos materiales. En esta vertiginosa dinámica la información y manipulación sobre el germoplasma, esto es, la sustancia hereditaria contenida en cada célula, se ha convertido en una línea fundamental de investigación científica y de preocupación política.

Se trata en suma de tecnologías de punta que podrán no sólo redefinir los requerimientos tradicionales de las grandes metrópolis, sino cambiar sustantivamente muchos de los procesos técnicos y económicos asociados a sus actividades agrícolas, pecuarias, pesqueras, etcétera. Ello sobre todo con base en tres áreas científico-tecnológicas de veloz desarrollo: el cultivo de tejidos, la fisiología microbiana y la ingeniería genética.

Pero ocurre que estas nuevas tecnologías conocidas como la biotecnología requieren para su funcionamiento eficaz una materia prima esencial que las haga posible: la biodiversidad, la riqueza genética. Y que Occidente, como señalamos antes, por su patrón de desarrollo homogeneizante excomulgó y persiguió implacable. Por fortuna, en los países no industrializados como el nuestro, la biodiversidad logró 
sobrevivir a pesar de todos los esfuerzos en contrario. Es decir logró sobrevivir no gracias al Estado, la universidad o las empresas, sino a pesar de ellas, y gracias al celo milenario, castigado y deformado muchas veces, de los grupos sociales marginados durante siglos de modernización occidental.

Logró sobrevivir porque esos grupos hicieron de la biodiversidad su eje medular de desarrollo, convirtiéndola en su más formidable herramienta de sobrevivencia. Logró sobrevivir porque esos pueblos buscaron conciliar la biodiversidad con otra diversidad no menos importante: la cultural, la social, la étnica. Una diversidad prohibida también por Occidente preocupado por borrar las caras y los pensamientos que no tengan la impronta blanca, cristiana y europea. Y así como se aniquilaron miles de especies animales y vegetales, en estos quinientos años las más de diez mil etnias que componían el mejor patrimonio de la humanidad se han reducido a menos de dos mil. Y naturalmente la contrapartida de esta destrucción étnica ha sido la depredación cultural, la uniformización cultural, la modernización cultural.

Así, la cultura milenaria que permitió al hombre andino conciliar la vida cotidiana con las aves y las fases de la luna, las plantas y las costumbres de la más variada fauna, fue dando paso a un esquema de hombre sin curiosidad ni interés por explicar la vida, el tiempo, la variedad biológica. Eso pasó a ser cosa de doctores, de gente sabia, seguramente universitarios.

El trabajador moderno, el candidato a ciudadano, es el que perdió la identidad con sus árboles, sus cerros, sus manantiales y la vida que le rodeaba. Su desarraigo lo ha uniformizado, no sólo porque dejó su terruño allá en los andes o la amazonia, sino porque mentalmente ya no es de ninguna parte.

Cómo entender entonces que este poblador andino gracias a su cultura perseguida, a su sentido común, a su interés e inquietud por entender y preservar la vida, haya devenido a la larga en el guardián que conservó a pesar de nosotros y, cómo no, para nosotros, la más formidable riqueza que nos ofrece el futuro.

Cómo entender la revalorización a que asistimos en instancias académicas, técnicas y financieras sobre todo del extranjero, de esa agricultura inmemorial practicada por nuestro campesinado indígena: de bajo consumo de energía fósil y con gran capacidad para conservar los recursos genéticos.

Explicar y comprender estos y otros procesos similares son desafíos de los que no pueden eximirse los historiadores. Pero de historiadores que deben resistir también la tentación de deleitarse con un neoindigenismo en que por definición todo lo pasado es lo mejor.

De lo que se trata, en suma, es de construir una historia destinada también a hacer comprensible y accesible el futuro. Una historia que juegue un papel activo en la formulación de opciones de desarrollo posibles para un país como el nuestro. Uno de los más pobres del planeta y al mismo tiempo con una riqueza ignota que pronto será objeto de saqueo por los países desarrollados No olvidemos que son éstos los que impulsan el desarrollo de las nuevas tecnologías. Y en particular las grandes corporaciones involucradas tradicionalmente en la producción de semillas, pesticidas, productos medicinales y alimentos. Para estas empresas, la participación nuestra en la aventura biotecnológica es bastante precisa: recolectores de especies para programas científicos que permitan la potenciación y transformación de sus sectores productivos.

La tarea entonces es cómo lograr revertir esa tendencia sin caer en el expediente fácil y exclusivo de convertimos en celosos guardianes de una biodiversidad manejada como preciada reliquia de museo, o a lo más, como monumental reserva natural. El desafío estriba entonces en ser capaces de utilizar esas nuevas tecnologías -sin descuidar obviamente las tecnologías que reposan en las ciencias convencionales, como las técnicas andinas y amazónicas- a fin de hacer más exitosos en términos de potencialidad, magnitud, economía y eficacia proyectos de desarrollo que incorporen a su eje medular de comprensión y de transformación del país tanto la biodiversidad como la diversidad cultural.

En suma, se trata de una estrategia que si bien sigue el mismo sentido de la sabiduría indígena de conservar, convivir y desarrollarse como colectivo asumiendo a plenitud nuestra heterogeneidad social, espacial y biológica, es capaz también de ubicarse frente a los retos y posibilidades que ofrece un cambiante entorno internacional. En fin, una estrategia que en ningún momento olvida que vivimos una revolución planetaria que puede llevarnos a buscar en el siglo XXI condiciones de existencia para el colectivo nacional mucho mejores que las actuales, o que puede, sin mucho esfuerzo, encasillarnos por otra centuria en la periferia de la periferia del sistema internacional.

\section{Notas}

Este artículo fue publicado en diciembre de 1993 en el Boletín de Antropología Americana, México. Su segunda publicación se da por la pertinencia $y$ actualidad del tema. 